ROCZNIKI HUMANISTYYCZNE

Tom LXVII, zeszyt 6 - 2019

DOI: http://dx.doi.org/10.18290/rh.2019.67.6-4

ZBIGNIEW DANEK

\title{
IZOKRATES NA TEMAT ETYCZNEJ WARTOŚCI PRZEKAZU RETORYCZNEGO
}

Przekonanie o ścisłym związku wzajemnym, w jakim pozostają język i etyka, nie wymaga szczególnych uzasadnień, skoro już prawdy moralne, których ugruntowanie stanowi nauka etyczna, mają swój wyraz w szeregu sformułowań zdaniowych. Można zresztą utrzymywać, że nawet pojedyncze słowa zyskują jakiś wydźwięk etyczny poprzez określone, często emocjonalne, nastawienie ich użytkowników do desygnatów, jakie ujmują, nie mówiąc już o wypowiedzeniach zdaniowych, które w naszych codziennych realiach niemal zawsze oddają jakiś stan rzeczy słuszny i pożądany, czy też zasługujący na ocenę przeciwną z punktu widzenia nadawcy oraz odbiorcy komunikatu. Pogląd o etycznym ładunku, czy też potencjale, który noszą w sobie słowa, jest też przynajmniej tak stary jak klasyczna myśl ateńskiego oświecenia, skoro znajduje sformułowanie już w pismach znakomitego ówczesnego teoretyka sztuki wymowy, jakim był Izokrates.

Izokrates wyrażając w swej ,pochwale logosu”" podziw i uznanie dla przekonującej mocy słowa, właśnie logosowi, czyli słowu, które konstytuuje myśl ludzką, przyznaje dokonania takie, jak stworzenie społeczności państwowych, praw, czy wynalezienie umiejętności. W owej ,pochwale słowa” skupia się jednak przede wszystkim na innej jeszcze zasłudze porozumienia słownego między ludźmi, jaką jest uformowanie obowiązujących w społecznościach przekonań na temat tego, co sprawiedliwe, a co niesprawiedliwe, co moralnie

Dr hab. ZBIGNIEW DANEK, prof. UŁ - Katedra Filologii Klasycznej; kierownik Zakładu Latynistyki i Językoznawstwa Uniwersytetu Łódzkiego; adres do korespondencji: ul. Pomorska 171/173, 90-236 Łódź; e-mail: zbigniew.danek@uni.lodz.pl

${ }^{1}$ Isocr. Nicocl. 5-9; idem: Antid. 253-7; por. Panegyr. 47-50. 
naganne, a co z drugiej strony piękne i szlachetne, wskutek czego staje się w ogóle możliwe wspólne istnienie ludzi w owych zbiorowościach ${ }^{2}$. Dzięki temu - wyjaśnia dalej - możemy etycznie dyskredytować tych, którzy źle postępują, pochwalać dobrze czyniących, pouczać nierozumnych, doceniać rozsądnych, a każde słowo wypowiadane sprawiedliwie i zgodnie z prawdą ocenić jako „obraz duszy dobrej i wiernej”"

W tej enkomiastycznej sekwencji „Nikoklesa” Izokrates nie ogranicza owego kreatywnego etycznie słowa jedynie do przekazu retorycznego, ani nawet do sfery naszej komunikacji werbalnej, skoro wspomina również o słowach, z pomocą których uświadamiamy sobie, co chcemy osiągnąć bądź zrealizować ${ }^{4}$, nie wyraża też - wbrew temu, co stwierdza Ch. Marsh - poglądu, że postęp w sferze moralności stwarza dopiero i rozwija wymowę oraz perswazywne zdolności człowieka ${ }^{5}$. Jasno daje do zrozumienia, że logos, czyli słowo, z pomocą którego myślimy i porozumiewamy się nawzajem, stanowi „ośrodek konstytucyjny”, z którego biora początek nasze przekonania moralne oraz regulacje prawne ${ }^{6} . \mathrm{Z}$ nacisku, jaki w swej „pochwale logosu” kładzie na ową etycznie kreatywną rolę języka, wynika, że właśnie moralność i zasady etyczne ceni szczególnie wśród osiągnięć kulturowo-cywilizacyjnych człowieka. Stosownie do tego przekonania formułuje też swój program przygotowania retorycznego i retorycznej praktyki, który można nazwać programem retoryki utrzymanej w pewnych ponadczasowych standardach etycznych.

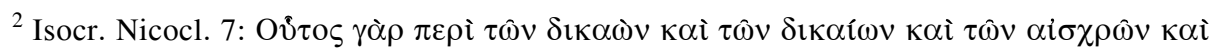

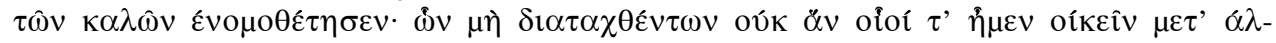
$\lambda \eta \dot{\eta} \lambda \omega v$.

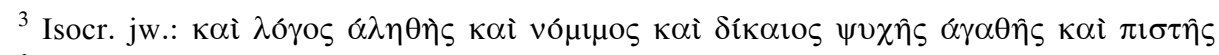

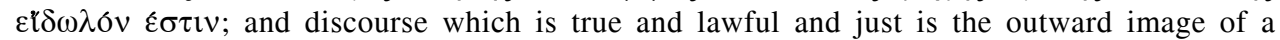
good and faithful soul [tłum. G. Norlin - edycja internetowa].

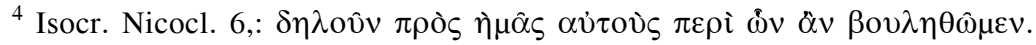

${ }^{5} \mathrm{Ch}$. MARsh, Millennia of discord: The controversial educational program of Isocrates, „Theory and Research in Education” 8(2010), 3, s. 289-303, s. 292: Isocrates clearly believed that moral development engendered and enhanced eloquence and persuasion. O tym, że przytoczone zdanie nie wytrzymuje próby również w aspekcie naszych doświadczeń indywidualnych, przekonuje twierdzenie Izokratesa, iż właśnie ćwiczenie w zakresie „mów politycznych” stanowi droge „,moralnego rozwoju” przyszłego retora - drogę, jaką nabywa on podstawowej wagi zalety etyczne (In soph. 21).

${ }^{6}$ Por. K.R. CHASE, Constructing Ethics through Rhetoric: Isocrates and Piety, „Quarterly Journal of Speech" 95 (2009), No. 3, s. 239-262; s. 244: Here, Isocrates places logos at the constitutive center of all that is good within human society, including laws, morality, and knowledge.
} 
Zamierzeniem piszącego niniejsze słowa jest ujęcie licznie obecnych w pismach Izokratesa mniej lub bardziej kategorycznych sądów dotyczących zasad etyki słowa, tak pożądanej w przekazie retorycznym owych czasów, w rodzaj katalogu, stanowiącego wykaz, i zarazem omówienie, podstawowych punktów wypracowanego przez niego programu retorycznego - programu retoryki konstruktywnej i zorientowanej na wartości, jakie mogły decydować o uzdrowieniu moralnym oraz politycznym ówczesnej społeczności ateńskiej. Opracowanie uwzględnia przede wszystkim wyrażane przez Izokratesa myśli o charakterze normatywnym, często postulatywnym, w drugiej kolejności jednak również stwierdzenia, w których deklaruje on własne etyczne przekonania, a także - jako trzecie źródło materiałowe - jego sądy wyrażające aprobatę, bądź dezaprobatę, dla określonych postaw i poczynań. Rekonstrukcję jego poglądów w kwestii etycznych zasad retorycznego oddziaływania ułatwia fakt, że - w przeciwieństwie do Platona, który niemal nigdy nie wypowiada się we własnym imieniu - w relacji, jaką kieruje ku swemu odbiorcy, daje on wyraz swoim osobistym przekonaniom i można mówić o „namacalnej” wręcz jego obecności w każdym takim przekazie ${ }^{7}$. Dzięki temu, również dzięki szczerości, z jaką ujawnia swoje słabości oraz dręczące go dylematy, Izokrates staje się z pewnością bliższy czytelnikowi niż inni współcześni mu autorzy ${ }^{8}$. Za pierwszy z tych dylematów można uznać wybór między prawdą a skutecznością retoryczną, wybór kłopotliwy dla każdego retora i polityka.

\section{PRAWDA I ODPOWIEDZIALNOŚĆ ZA SŁOWO}

Jeżeli w rozważaniu nad wymogiem głoszenia prawdy w przekazie retorycznym odniesiemy się do realiów życia politycznego, łatwo dojdziemy do przekonania, iż ma tu miejsce sytuacja stanowiąca odwrotność słynnego paradoksu Eubulidesa: „kłamca mówi, że kłamie”, jako że wszyscy, którzy wypowiadają się publicznie, zastrzegają, że głoszą wyłącznie prawdę. Sama natomiast prawda jest taka, że mówca absolutnie szczery w swych wypowiedziach z reguły ustępuje pokonany, natomiast ci, którzy składają obietnice

\footnotetext{
${ }^{7}$ Por. E. HASKIns, Logos and Power in Sophistical and Isocratean Rhetoric, w: Isocrates and Civic Education, red. T. Poulakos, D. Depew, Austin: University of Texas Press 2004, s. 84-103; s. 98: Isocrates' palpable presence in most of his compositions.

${ }^{8}$ Więcej na ten temat: Z. DANEK, ,Lider o stabym głosie”, czyli wizerunek własny Izokratesa, praca przyjęta do druku w piśmie „Meander”.
} 
bez pokrycia, łatwo trafiają do przekonania ogółu. Dostrzega taki stan rzeczy Izokrates, który już w swojej mowie „Przeciw sofistom” piętnuje ówczesnych nauczycieli mądrości i skutecznej wymowy jako tych, którzy obiecują coś, czego ich sztuka i w ogóle żadne wychowanie nie jest zdolne dokonać, mianowicie przyszłe szczęśliwe życie dzięki umiejętności przewidzenia tego, co nastąpi, oraz biegłości w dziedzinie skutecznej wymowy (In soph.1-3, 9-12). Głównym punktem oskarżenia jest zarzut, że w imię swych partykularnych

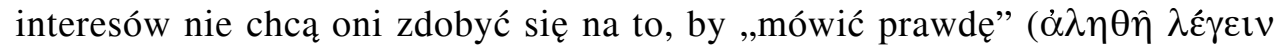
- In soph. 1), w przeciwieństwie do Izokratesa, który jawnie przyznaje, że nie ma wychowawczej umiejętności, która osobom z natury niezdolnym wpoiłaby etyczną doskonałość i biegłość retoryczną (In soph. 15, Antid. 274-5), a retor wychowawca może pracować jedynie nad tym, by ucznia z odpowiednimi predyspozycjami doprowadzić do perfekcjonistycznego opanowania sztuki wymowy (Antid. 292). Deklaracja takiej treści może być dowodem na to, że w przeciwieństwie do owych sofistów Izokrates jako nauczyciel wymowy nie kieruje się doraźną ambicją pozyskania za wszelką cenę przysparzającego zysk „klienta”, skoro może on takimi deklaracjami zniechęcić do siebie adeptów sztuki wymowy oczekujących łatwych i pewnych rezultatów, zwłaszcza że zapowiada swoim uczniom uciążliwe ćwiczenia nie tylko w zakresie biegłości retorycznej (Antid. 187, 247, 292).

Postulat głoszenia prawdy otwiera dla Izokratesa wszelkie rozważania na temat dobrze pojętej retoryki, jest też nieustającą deklaracją, jaka pada z jego strony, gdy mówi o samym sobie. W najbardziej znaczących swoich pismach podkreśla, że to, co stwierdzi, bądź stwierdził, jest czystą prawdą (Antid. 11, Panath. 271), zastrzega też ustawicznie, że owej prawdy się trzyma9 ${ }^{9}$, deklaruje martyrologiczną wręcz gotowość poświęcenia swego bezpieczeństwa dla prawdy (Antid. 272), czyni wreszcie postulat prawdomówności mówcy publicznego przedmiotem swoich zaleceń dydaktycznych. Kieruje je do Tymoteusza, przyszłego męża stanu, nakłaniając go, by w swych wystąieniach publicznych stosował „spośród słów te, które są najbardziej prawdziwe i sprawiedliwe" ${ }^{10}$. Zwracając się z kolei do członków trybunału, przed którym występuje, wyraża przekonanie, że nie będą oni tkwić w sferze sądów, czy też mniemań $-\delta \delta \xi \alpha$, lecz wraz z nim podążą za prawdą ${ }^{11}$.

\footnotetext{
${ }^{9}$ Por. Antid. 11, 13, 15, 37, 44, 50, 76 itd.

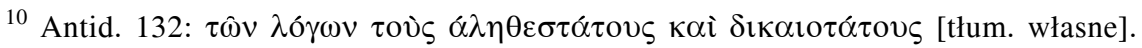

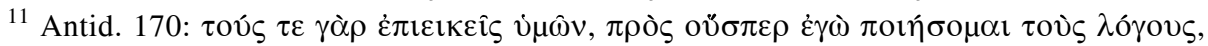

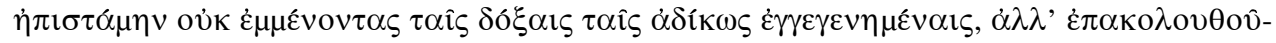
$\nu \tau \alpha \varsigma \tau \alpha \hat{\imath} \varsigma \dot{\alpha} \lambda \eta \theta \varepsilon i \alpha i \varsigma$.
} 
Tę ostatnią deklarację można odebrać jako odejście od retorycznej pragmatyki, która również Izokratesowi nakazuje przyznać, że sąd w praktyce życia codziennego więcej znaczy niż dochodząca prawdy wiedza ${ }^{12}$, a retor powinien dążyć przede wszystkim do tego, by wzbudzać u słuchaczy określone sądy na swój temat (Antid. 278). Porównanie tej treści konstatacji z powyższymi deklaracjami prawdomówności może owocować zarzutem podwójnej gry, jaką prowadziłby ów retor $\mathrm{z}$ adresatem swoich pism, zarzut ten jednak odsuniemy łatwo, jeżeli za F.Waltersem przyjmiemy, iż w myśl programu retorycznego Izokratesa mówcę winna cechować zdolność do tego, by nadać niepewnemu jeszcze sądowi moc, czy też rangę, niekwestionowanej wiedzy - episteme $e^{13}$. By mogło się to dokonać, wystarczy sprawić, by owe sądy tak własne wypowiadającego się publicznie, jak też sądy, które wzbudza u swoich słuchaczy - zyskały wartość tak pożądanej przez Izokratesa prawdy.

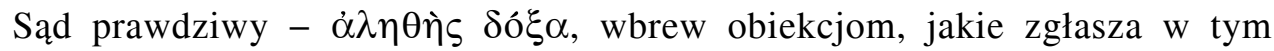
względzie Platon (Tht. 201a-c), w realiach politycznych bądź sądowych będzie już równoznaczny z wystarczającą wiedzą o sytuacjach, które stanowią przedmiot uwagi audytorium.

Co jednak stanie się w sytuacji, gdy owa prawda przyniesie rozstrzygnięcia niekorzystne dla retora? W tym właśnie punkcie zaznacza się istotna różnica między Izokratesem a mówcami owych czasów, dla których stawką i miarą skuteczności retorycznej było z reguły osiągnięcie doraźnego celu, to znaczy przekonanie słuchaczy do rozwiązań, jakie proponowali, bez względu na wagę aksjologiczną przedkładanych argumentów. Izokrates programowo wystrzega się takiego służącego wyłącznie doraźnym celom postępowania, dystans ten może jednak znamionować nie tyle nieskazitelność etyczną, ile określoną strategię twórcy o ambicjach większych niż aspiracje ówczesnych autorów mów sądowych. Dążąc do uzyskania pozycji duchowego przywódcy ówczesnej społeczności greckiej ${ }^{14}$, a mając zapewne na względzie również

\footnotetext{
${ }^{12}$ Isocr. Helen. 5, In soph. 8, Antid. 184, Panath. 9; por. Ch. EUCKEN, Isokrates. Seine Positionen in der Auseinandersetzung mit den zeitgenössischen Philosophen, Berlin 1983, s. 284: In der Sophisterede präsentiert Isokrates seine Bildungsmethode und macht... Doxa zum entscheidenden Massstab im Handeln.

${ }^{13}$ F.D. WALTERS, Isocrates and the Epistemic Return: Individual and Community in Classical and Modern Rhetoric, „Journal of Advanced Composition” 13(1993), s. 155-72, s. 156: a power to invest doxa, the expression of uncertain opinion, with the force of certain knowledge, episteme.

14 Autorzy opracowań ujmują ową pozycję retorycznego przywódcy słowami „leader of

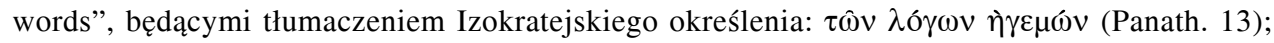
por. YUN LEE TOO, The Rhetoric of Identity in Isocrates, Cambridge: Cambridge University Press 2009 (first publ. 1995), s. 138, 139, 146, 150; E. HASKINS, Logos and Power, s. 96.
} 
„odległych w przestrzeni i w czasie czytelników” swoich pism ${ }^{15}$, nie może on sobie pozwolić na to, by podejmować tematy błahe i wyzwania o charakterze doraźnym, musi też z drugiej strony dbać o to, by własny jego wizerunek pozostał nieskazitelny - nie skalany fałszem, dyktowanym niezdrowa ambicją agonistyczną. Jeden i drugi z tych motywów zasługuje na dokładniejsze omówienie.

\section{NIESKAZITELNOŚĆ ETYCZNA}

Kolejnym i z pewnością nie mniej ważnym punktem programu retorycznego Izokratesa jest postulat czyniący przedmiotem uwagi samą sylwetkę retora, mianowicie wymóg, by prezentował on własną osobą niekwestionowaną etyczną wartość ( $\dot{\rho} \rho \tau \tau \hat{)}$ ), ujmowaną jednak w relatywnym nieco kontekście społecznej opinii na temat tegoż mówcy. Czytamy: „Niech ten, kto chce mówić w sposób przekonujący, nie wyzbywa się troski o własną etyczną wartość, lecz to zwłaszcza ma na względzie, by zyskał jak najprzyzwoitszą opinię $(\delta \sigma \xi \alpha)$ u współobywateli" " . Nie otrzymujemy jeszcze w tym miejscu wyjaśnienia, na czym polegać ma ta ludzka wartość, Izokrates określa ja

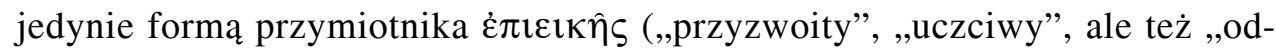
powiedni”, „stosowny”), dodając następnie, że taki doskonały mówca dążyć

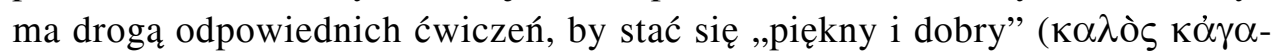
$\theta \delta \varsigma)$. Ten nieco truistyczny slogan, a także występujące rzeczywiście dość

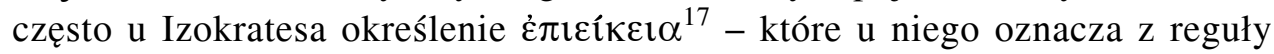
ogólnie pojętą ludzką przyzwoitość czy uczciwość i też w sumie niewiele

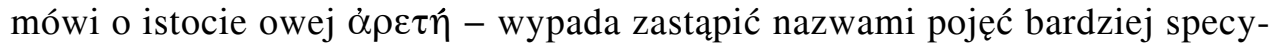
ficznej treści, wprowadzającymi jakieś komponenty ujmowanej kompleksowo wartości ludzkiej. K.R. Chase uznaje, że najbardziej odpowiednie będą tu nazwy „sprawiedliwości” (dikaiosynēe i „roztropności” (sophrosyne $\bar{e}$, za który-

\footnotetext{
${ }^{15}$ Por. J. JANIK, Izokrates - pisarz czy mówca? Kilka uwag o kompozycji „Panegiryku”, „Quaestiones Oralitatis” 2(2016), nr 1, s. 55-74; s. 72: Można z łatwością wyobrazić sobie, że dla autora Panegiryku odległy w przestrzeni (i być może w czasie) czytelnik był nie mniej rzeczywisty, niż stojący przed mównicą współobywatel.

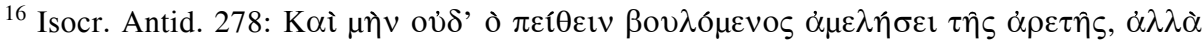

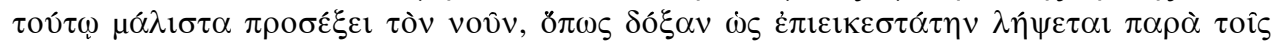

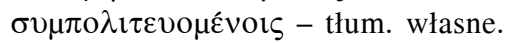

${ }^{17}$ Np. Isocr. In soph. 21, Antid. 195, 212, Paneg. 63; por. Antid. 142, 164, 170, 223, Panath. 263.
} 
mi pójda „pobożność”, „odwaga” i „mądrość” oraz ludzka „ogólnie pojęta doskonałość"18.

Nie wnikając w całość nauki etycznej, jaką znajdziemy w pismach Izokratesa, należy zauważyć, że w kontekście programu retorycznego, który zaryso-

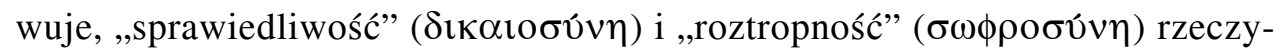
wiście przedstawiają się jako podstawowe zalety decydujące o właściwym przygotowaniu mówcy do pełnionej przez niego misji społecznej. Stwierdza on, że przyszły retor, aby potrafił ,dobrze mówić” ( $\lambda \varepsilon \hat{\varepsilon} \varepsilon \imath \mathcal{\varepsilon} \mho \hat{)}$, przede wszystkim musi mieć wpojone owe dwie cechy charakteru, nie uczyni tego jednak nauka zwodniczych sofistów, lecz słowom mówcy nada tę moc jego osobista ambicja i staranie o własne ,wzbogacenie się" (Antid. 274-5). Owo „wzbogacenie się”, czy też „korzyść” ujmuje Izokrates charakterystycznym terminem $\pi \lambda \varepsilon_{\text {cov }} \xi \hat{i} \alpha$, kojarzącym się z intratną praktyką krytykowanych przez niego sofistów, co sprawia, że zastrzega on natychmiast, iż nie jest to „korzyść” w znaczeniu, jakie nadają temu określeniu ludzie nierozumiejący istoty pojęcia, lecz „korzyść” w słusznym rozumieniu słowa.

Jak należy to słowo rozumieć, wyjaśnia on nieco dalej, ujmując treść określenia $\pi \lambda \varepsilon o v \varepsilon \xi \hat{\imath} \alpha$ na dwóch płaszczyznach. Otóż „więcej mają” i naprawdę wzbogacają się w aspekcie naszych powinności względem bogów ludzie najpobożniejsi i najgorliwiej oddani praktykom religijnym, natomiast na płaszczyźnie stosunków międzyludzkich ci, którzy pozostają w jak najlepszych relacjach ze swymi współobywatelami, a sami cieszą się opinią ludzi najszlachetniejszych ${ }^{19}$. Dodajmy, iż ta budująca refleksja nad treścią określenia „wzbogacać się” nie jest u Izokratesa odosobniona, skoro już w mowie „O pokoju” dowodzi, że prawdziwą korzyść odnoszą jedynie ci, którzy z oddaniem praktykują pobożność i sprawiedliwość (De pace 33), a w później-

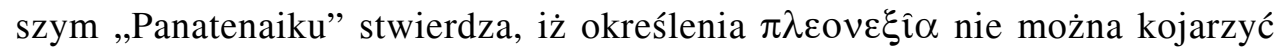
z ludźmi, którzy nie dotrzymują zobowiązań, bądź dopuszczają się oszukańczych praktyk (Panath. 254). Nie można też nie zauważyć, że w każdej ze wskazanych sytuacji owo etyczne ,wzbogacenie się" nie przychodzi bez trudu, a przynajmniej uczciwej pracy, i ten właśnie akcent „starania” -

\footnotetext{
${ }^{18}$ K.R. CHASE, Constructing Ethics, s. 243: Nonetheless, Isocrates consistently included justice (dikaiosyne $\overline{\text { ) }}$ and moderation (sophrosyne $\overline{\text { ) }}$. To these two core virtues, he added piety, courage, wisdom, and general excellence (arete).

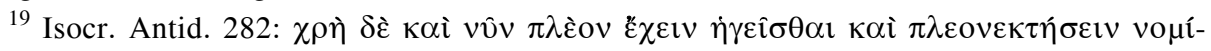

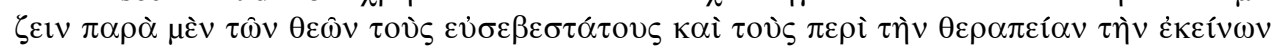

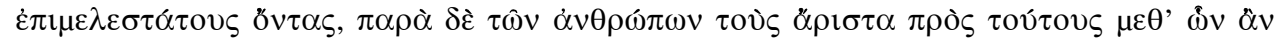

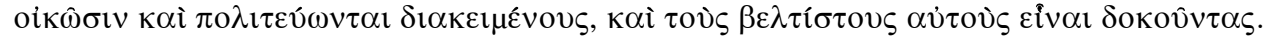




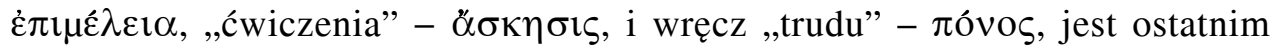
istotnym elementem, który dopełnia zarysowanej przez Izokratesa sylwetki właściwie przygotowanego mówcy i zarazem obywatela. Nacisk, jaki kładzie on na konieczność dołożenia wysiłku do przygotowania retorycznego, jest tak silny, że wybrzmiewa określeniem ,umiłowanie trudu” ( $\phi 1 \lambda \mathrm{o} \pi \mathrm{ov} \tilde{\alpha} \alpha)$, a stwierdza też Izokrates - nieco wbrew temu, co utrzymywał wcześniej - że pracę, staranie $(\dot{\varepsilon} \pi \mu \hat{\varepsilon} \lambda \varepsilon \imath \alpha)$ należy cenić więcej niż dyspozycje będące darem naturalnym (Antid. 291-2). Warto może dodać, iż tak ścisły związek umiejętności stricte retorycznej z postawą reprezentująca wysokie standardy etyczne stanowi ewenement nie tylko na ogólnym tle ówczesnej mało dbającej o przyzwoitość retoryki, lecz również w konfrontacji z teorią wymowy Arystotelesa, który jednak nie łączył słusznego, to znaczy skutecznego, mówienia ze słusznym działaniem i słuszną postawą życiową ${ }^{20}$.

W związku z tym, że Izokrates stwarzając tak bardzo etyczny obraz retora, podkreśla jednak ustawicznie znaczenie opinii - $\delta \sigma \xi \alpha$, jaką cieszy się mówca u tych, do których przemawia, powraca pytanie, w jakim stopniu owa kreacja wizerunkowa ma charakter fasadowy, czyniąc warunkiem powodzenia mówcy pewien $\mathrm{w}$ istocie pozór, to znaczy wrażenie, jakie stwarza swoja osobą, a na ile uzależnia ona oddziaływanie retoryczne od rzeczywistej, immanentnej obecności wskazanych powyżej cnót etycznych w postawie i postępowaniu retora. Pytanie jest o tyle trudne, że wiąże się z moralną oceną intencji samego Izokratesa, niemniej już na podstawie wziętych pod uwagę jego myśli można stwierdzić, że mamy raczej do czynienia z kreowaniem istotnych wartości etycznych, co zarazem nie przeszkadza temu, że są one relatywizowane w kontekście społecznej recepcji osoby i zachowań mówcy publicznego. Co więcej, omówione sytuacje wskazują na to, że wymaga Izokrates koniunkcyjnej obecności jednego i drugiego warunku, tego mianowicie, by właściwie przygotowany retor zarówno był osobą etycznie nieposzlakowaną, jak też taki się wydawał; niedopełnienie nawet jednego z tych wymogów postawi mówcę na przegranej z góry pozycji.

\footnotetext{
${ }^{20}$ Por. E. Garver, Philosophy, Rhetoric, and Civic Education in Aristotle and Isocrates, w: Isocrates and Civic Education, s. 186-213, s. 190: [Aristotle] distinguishes between speaking well and acting well, while Isocrates' rhetoric as an practical art depends on their identity.
} 


\section{POWAGA TEMATU I ZAANGAŻOWANIE POLITYCZNE}

Kolejny punkt w katalogu wymogów, jakie stawia Izokrates przed dobrze przygotowanym retorem, stanowi $\mathrm{w}$ istocie uzupełnienie listy powyższych tak bardzo etycznych dezyderatów, uzupełnienie na tyle jednak ważne, że staje się sztandarową pozycją zbioru zasad, jakie wpaja on adeptom umiejętności retorycznej. W trakcie swego wykładu na temat właściwego przygotowania mówcy stwierdza mianowicie, że ten, kto chce wygłaszać lub pisać mowy zasługujące na pochwałę, nie może wypowiadać się w sprawach niesłusznych, lecz także w sprawach małej wagi i dotyczących prywatnych umów czy roszczeń, a powinien podejmować tematy ,wielkie, piękne, służące dobru człowieka oraz odnoszące się do spraw, którymi żyje wspólnota"21. Dodajmy, że sam Izokrates wierny tej zasadzie programowo stroni od tego, by angażować się chociażby w spory sądowe, dementuje też z oburzeniem pogłoski, jakoby miał się parać tak zwaną logografią, czyli pisaniem mów procesowych (Antid. 2). Poświęca swą uwagę sprawom naprawdę doniosłym, za jakie uznaje istotne kwestie o znaczeniu politycznym, i w tym też kierunku przysposabia swych podopiecznych, kreując z nich przyszłych przywódców państwowych i mężów stanu.

Gwoli dokładności należy zauważyć, iż programowy swój postulat, w myśl którego retor winien poświęcić swą sztukę i zdolności sprawom poważnym, rozwija Izokrates w dwóch kierunkach. W znanym już wywodzie na temat dobrze pojętej retoryki (Antid. 258-292), dając wyraz niskiej swej ocenie dialektyki oraz spekulacji filozoficznej poświęconej kwestiom ontologicznym, wyraża pogląd, iż adepci retorycznej umiejętności mogą początkowo oddawać się takim ćwiczeniom, niemniej na dalszym etapie studiów winni już skupić swój wysiłek intelektualny na studiach filozoficznych we właściwym znaczeniu słowa. Za takie uznaje Izokrates przygotowanie do tego, by w przyszłości „pięknie zarządzali oni zarówno własnym domem, jak też sprawami wspólnymi, czyli sprawami państwowymi" ${ }^{22}$. Prezentując taki punkt widzenia odwra-

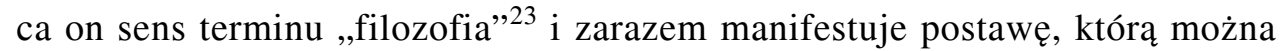

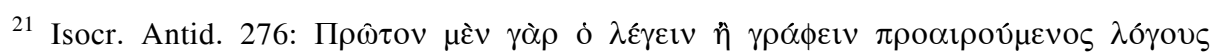

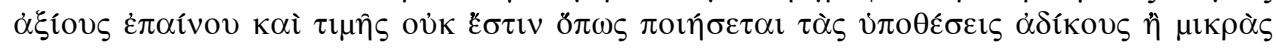

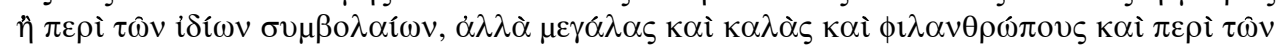

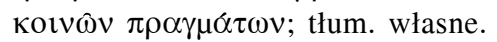

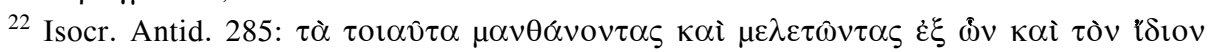

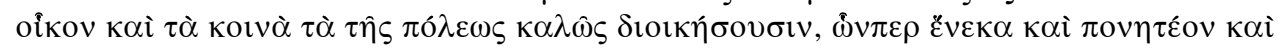

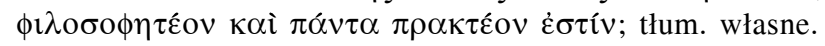

${ }^{23}$ Wchodząc tym samym w pewien konflikt z Platonem i jego czysto spekulatywną koncepcją filozofii. 
nazwać „odwrotem epistemologicznym”, czy raczej „odwrotem od naukowości”, to znaczy odejściem od rozważań dialektycznych i filozofii przyrody ku tematyce, ujmując rzecz $\mathrm{w}$ uproszczeniu, politycznej ${ }^{24}$. Uproszczenie polega na tym, że Izokratejskie studia sensu lato retoryczne są, na co wskazuje powyższy cytat, dwukierunkowe, czy też dwustopniowe. Uproszczenie to wydaje się jednak o tyle dopuszczalne, że zasadniczym i finalnym punktem programu edukacyjnego jest dla Izokratesa przygotowanie retora do tego, by mógł uczestniczyć w sprawach państwa i tej właśnie politycznej retoryce podporządkowane zostają wszystkie inne rodzaje, czy też zastosowania, owej sztuki ${ }^{25}$.

Wskazują na to nie tylko wytyczne programu edukacyjnego Izokratesa, lecz jeszcze bardziej wymownie deklaracje, jakie czyni on na temat własnej swojej postawy i aspiracji. Zastrzega przede wszystkim, że w przeciwieństwie do ogółu ówczesnych retorów, nieprzebierających w środkach i doborze tematów, on sam dba o to, by wypowiadać się wyłącznie w sprawach poważnych (Panath. 15, 34, 271), a i u osób, których opinia coś znaczy, cieszy się autorytetem człowieka poważnego (Panath. 8). Nie ulega też wątpliwości, że w tym względzie ma na myśli sprawy poważniejsze niż zawiadywanie własnym majątkiem, skoro własną twórczą aktywność poświęca ,wymowie o treści politycznej”, to znaczy skupionej na sprawach polis, której jest obywa-

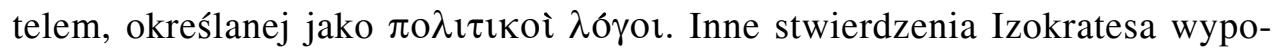
wiadane w tej kwestii pozwalają zrozumieć, że jego „polityczne” zaangażowanie nie ma charakteru szowinistycznego czy też separatystycznego. Wykracza ono poza wąsko pojęte interesy Aten, w poszukiwaniu idei, która jednoczyłaby, lecz i uczyniłaby szczęśliwszą, całą populację ówczesnych Greków. Wyjaśnia on bowiem, że należy do tych autorów, którzy decydują się tworzyć mowy poświęcone nie interesom prywatnym, lecz sprawom wszystkich Hellenów, sprawom ,politycznym” i sprawom, jakie winny być omawiane na uroczystym ogólnonarodowym zgromadzeniu ${ }^{26}$, dodając w nieco późniejszej swojej wypowiedzi, że jako tematykę swoich mów obrał sprawy „helleńskie,

\footnotetext{
${ }^{24}$ Por. F.D. WALTERS, Isocrates and the Epistemic, s. 156: an „epistemic return”, [...] as a turning ,away from treatises on dialectics and natural philosophy” to a concentration „on writing political discourses and on political science itself".

${ }^{25}$ Por. YUn LeE ToO, The Rhetoric, s. 7: For Isocrates logos politikos is the only legitimate language for a cicitien and thus one to which all other discourses must be either subsumed or subordinated.

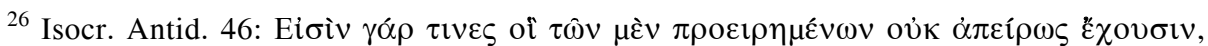

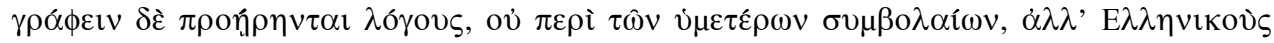

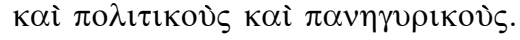


królewskie i polityczne"27. Odniesienie do władzy królewskiej, jakie czyni on $\mathrm{w}$ tej retrospektywnej wypowiedzi, dokumentuje zarazem jego otwarty stosunek do spraw ustrojowych, uznawał bowiem, że mądrze konstytuowana monarchia nie jest ustrojem, który winien ustąpić demokracji, i temu swojemu przekonaniu dawał wyraz w szeregu mów, jakie kierował do ówczesnych władców. Komentarza domaga się przede wszystkim jednak odwołanie do uroczystości gromadzącej Hellenów, jakie pada w pierwszej z przytoczonych wypowiedzi. Jest to dość wyraźna aluzja do mowy zwanej „Panegyrykiem”, w której Izokrates nawołuje Greków do zjednoczenia się i wspólnej wyprawy przeciw Persom, dającej nadzieje na pozyskanie nowych urodzajnych terenów kolonizacyjnych.

Można przyjąć, że składając deklaracje takiej treści Izokrates również swoim uczniom, adeptom dobrze pojętej sztuki wymowy - pomijając innych adresatów tych wypowiedzi - przedkłada własny przykład jako wymowny „paradygmat" słusznej postawy etycznej i obywatelskiej retora, co pozwala traktować owe deklaracje również jako środek, czy metodę oddziaływania dydaktycznego i zarazem prezentację bodaj najważniejszego punktu programu retorycznego Izokratesa. Jest to program retoryki otwartej na „postulaty życia politycznego" i czyniącej z młodych adeptów retorycznej umiejętności „dobrych obywateli dla swego państwa ${ }^{28}$.

\section{4. ŻYCZLIWOŚĆ I PRZYJAZNY KONSTRUKTYWIZM}

Kolejna zasada retorycznej etyki, którą Izokrates wpaja swoim uczniom oraz rekomenduje własnym przykładem, jest postulatem wychodzącym naprzeciw określonym preferencjom adresata wystąpienia publicznego i można ją kwalifikować również jako swoistą instrukcję o charakterze strategicznym. Dowiadujemy się o niej z wytycznych, jakie daje ów retor wspomnianemu już Tymoteuszowi, uczulając go na to, że w życiu publicznym słuchacze wolą dowiadywać się rzeczy przyjemnych i darzą większą sympatią tych, którzy zabiegają o miłe przyjęcie swoich wypowiedzi, niż swych rzeczywistych

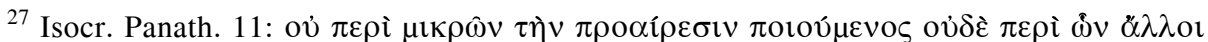

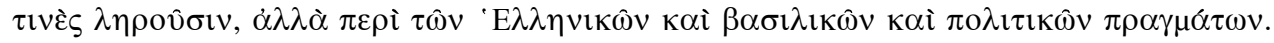

${ }^{28}$ Por. T. Poulakos, Speaking for the Polis. Isocrates' Rhetorical Education, Columbia: University of South Carolina Press 1997, s. 105: Isocrates' rhetorical education put into practice Protagoras' vision of rhetoric as an art that could be infused with the demands of political life and could make students of rhetoric good citiziens for the polis.
} 
dobroczyńców, a nawet tych, którzy ich zwodzą „promieniejąc” radością i życzliwością względem ludzi, niż polityków zachowujących godność i powagę $^{29}$. Izokrates stara się $\mathrm{w}$ ten sposób nadać wagę zaleceniu, w myśl którego działacze polityczni winni zważać na to, by tak w słowach, jak i w postępowaniu okazywać swą łaskawość i życzliwość w stosunku do ludzi ${ }^{30}$.

Powracający dylemat, w jakim stopniu szczera, a w jakim jedynie wizerunkowa ma być ta życzliwość, wypada i tym razem rozwiązać koniunkcyjnie, przyjmując współobecność motywów jednego i drugiego rodzaju, zwłaszcza że i w tym względzie Izokrates czyni wyznania dające świadectwo jego własnej i nieprzymuszonej ku innym życzliwości. Stwierdza, że wstydziłby się, gdyby radząc innym zamiast ich dobra miał na uwadze osobisty pożytek i nie zalecałby im tego, co dla nich najlepsze z wszystkich możliwych korzyści ${ }^{31}$. Tę życzliwość - Eưvor $\alpha$, łączoną z elementami ,akceptacji, sympatii i gotowości do niesienia pomocy" ${ }^{32}$, potwierdza niekiedy literalnie (Demonic. 2, 44), w większości jednak nieustanną gotowością do świadczenia dobra własnej polis oraz wszystkim Hellenom, deklarowaną słowem oraz czynem. Zarówno przykład, jaki sam daje, jak i czynione przez niego zalecenia teoretyczne - postulat odzywa się także w mowie „O zamianie majątku” (Antid. 276) - pozwalają zgodzić się ze stwierdzeniem, że „wiele spośród mów Izokratesa podkreśla znaczenie życzliwości w życiu politycznym" ${ }^{33}$.

$\mathrm{Z}$ włączaną w kodeks etyczny retora życzliwością łączy się też u Izokratesa odpowiedni sposób bycia, znamionujący kulturę osobistą mówcy publicznego, a także - w konsekwencji - postawa otwartości i zrozumienia dla potrzeb i aspiracji drugiej strony retorycznej interakcji, to znaczy odbiorcy komunikowanych przez retora treści. Izokrates podkreśla, że on sam jest „wiele łagodniejszy” niż jego oponent, zarzucający mu polemiczną zapalczy-

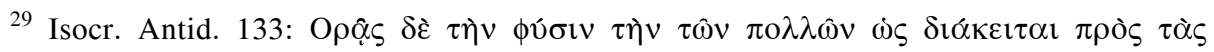

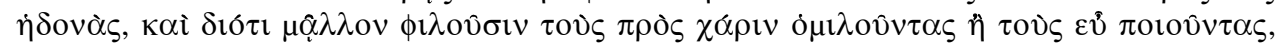

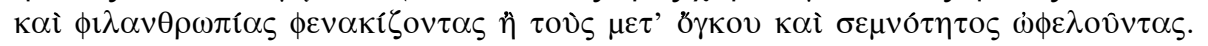

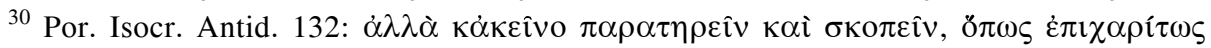

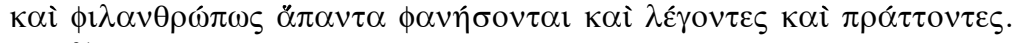

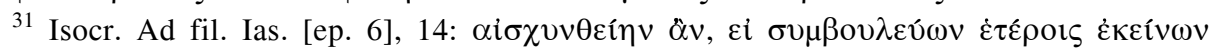

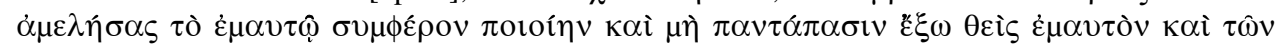

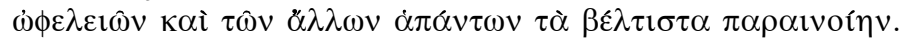

32 Por. J. de Romilly, Eunoia in Isocrates or the Political Importance of Creating Good Will, „The Journal of Hellenic Studies” 78(1958), s. 92-101; s. 92: Eunoia, in Greek, is something more than good will; it means approval, sympathy and readiness to help.

${ }^{33}$ YUn LEE TOO, The Rhetoric, s. 167: many of Isocrates' speeches stress the theme of ,good-will” in political affairs.
} 
wość (Antid. 260), nigdy też nie wypowiada się autorytarnie i w sposób nakazowy, lecz zawsze z dużą powściągliwością, niemałą dozą samokrytycyzmu i gotowością do ustępstw w przypadku, gdyby nie miał racji. Tą swoją postawą, pełną szacunku dla adresata jego wypowiedzi i otwartą na ewentualne racje przeciwne, daje świadectwo wypracowanej przez siebie koncepcji retoryki „symetrycznej” - retoryki, w której „obie strony zwyciężają"34, odchodzącej zdecydowanie od Gorgiańskiej koncepcji logosu, będącego bezwzględnym władcą ( $\delta v v o ́ \sigma \tau \eta \varsigma)$ umysłów słuchaczy, dalece też odmiennej od manipulatywnej w istocie sztuki wymowy, której wizję zarysowuje Platoński „Fajdros”. W tym bowiem dialogu Platona nawet modyfikacje służące podniesieniu wartości epistemologicznej retorycznej umiejętności, nie sprawiają, że logos, czyli słowo retora, przestaje być „władcą" panującym nad umysłami słuchaczy, którzy bezwolnie ulegają perswazji słownej. Izokrates zdecydowanie łagodzi taki autokratyczny obraz słowa jako wszechwładnej broni retora, wychodząc z koncepcją, w myśl której staje się ono jedynie „przewodnikiem” - $ү \gamma \varepsilon \mu \omega \nu$, łagodnie prowadzącym słuchacza ku słusznym decyzjom i właściwemu postępowaniu ${ }^{35}$. Ta, jakże etyczna, koncepcja oddziaływania retorycznego w znakomity sposób puentuje myśli Izokratesa głoszące potrzebę życzliwości, łagodności i szacunku retora dla każdego adresata swojego przekazu.

\section{NIEUSTAJĄCA AKTYWNOŚĆ MYŚLOWA}

Następny z postulatów, jakie stawia przed mówcą publicznym Izokrates w swoim programie opartej o etyczne zasady retoryki, wkracza swą treścią w nieco inną już sferę etyki, powiedzielibyśmy, zawodowej etyki retora i należy do zaleceń o charakterze „operacyjnym”, służących zarazem temu, by wypowiedź retoryczna reprezentowała odpowiednio wysoki standard ,gatunko-

\footnotetext{
${ }^{34}$ Por. Ch.W. MARsh, Public Relations Ethics: Contrasting Models from the Rhetorics of Plato, Aristotle, and Isocrates, „Journal of Mass Media Ethics” 16(2001), 2-3, s. 78-98; s. 88: Because Isocratean rhetoricians seek unification and consensus [...] they consider the interests and arguments of others in a debate; por. s. 89: the Isocratean rhetorician seeks to attain goals by building relationships in which both parties win.

35 Por. J. Poulakos, Rhetoric and Civic Education: from the Sophists to Isocrates, w: Isocrates and Civic Education, s. 69-83; s. 69: I show that whereas the Sophists held a dynastic conception of logos, Isocrates maintained a hegemonic one; por. E. HASKINS, Logos and Power, s. 84: the difference between Gorgias' and Isocrates' terms for logos - dunastes versus hegemon - indicates radically divergent perspectives on the relationship between rhetoric and power.
} 
wy". Dość czytelnie artykułuje on ten aksjomat wtedy, gdy zwraca się przeciw nauczycielom wymowy, którzy „próbują oprzeć na ustalonych regułach dziedzinę wymagającą twórczego podejścia"36. Odrzucając taką sofistyczną retorykę, schematyczną i wyzbytą inwencji twórczej ${ }^{37}$, formułuje Izokrates własne dezyderaty, w myśl których należyte przygotowanie i wygłaszanie mów wymaga „duszy dzielnej i pomysłowej” "38, to znaczy kogoś, kto stosując odpowiednie do sytuacji ,idee” i będące wytworem osobistej inwencji argumenty, czyli ,enthymematy” ( $\dot{v} \theta v \mu \eta \tilde{\mu} \mu \alpha \tau)$, zawsze będzie umiał wyjść

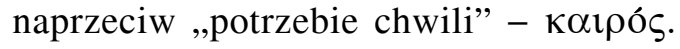

O ile pierwszy z przytoczonych trzech terminów może jeszcze oznaczać pewne „schematy” myślowe czy też pojęciowe, którymi jednak należy posługiwać się w sposób absolutnie nieschematyczny, o tyle już dwa następne wiążą się ściśle z wymogiem nieustającej pracy myślowej retora, pracy twórczej, służącej dostosowaniu treści i sposobu mówienia do sytuacji, w jakiej przemawia, oraz nastrojów i oczekiwań słuchaczy. O powodzeniu mówcy

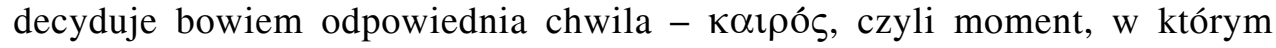
stan umysłów słuchaczy jest taki, a nie inny, i odpowiadający tej potrzebie chwili moment samego wystąienia, którego treść i forma musi być modyfi-

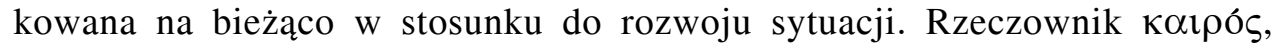
który w jakiś sposób relatywizuje wartość przekazu retorycznego, ujmuje jak zauważa Ch. Marsh - jedną i drugą stronę tego interaktywnego procesu komunikacyjnego ${ }^{39}$.

Kreatywność retora wyraża się tym, że znajduje on i formułuje odpowiednie do sytuacji „enthymematy”, które - jak zauważa Izokrates - nie tylko dodają mowie siły przekonywania, lecz także podnoszą jej walor estetyczny (In soph. 16). Sam termin ,enthymemat”, standardowo oddawany jako ,argument”, nie oznacza w żadnym wypadku argumentu będącego jakąś prawdą obiegową. Jest to - w aspekcie etymologicznym - myśl, która rodzi się „wewnątrz", to znaczy w świadomości myślowo aktywnego podmiotu ${ }^{40}$. Sam

\footnotetext{
${ }^{36}$ Isocr. In soph. 12 - tłum. M. Dobrek („Meander” 62(2007), 3-4, s. 236).

37 Por. T. WAREH, The Theory and Practice of Life. Isocrates and the Philosophers, Cambridge: Harvard University Press 2012, s. 29 (Isocrates' rejection of sophists' cookbooklike approaches).

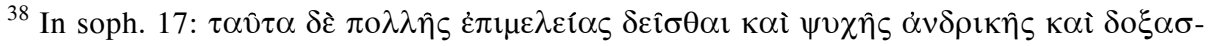

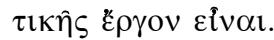

${ }^{39}$ Ch. MARsh, Millenia, s. 297: Kairos, thus, is not only the right moment in time; it also is the right moment in the discourse; por. s. 298: kairos, for Isocrates, involved not only seizing the opportune moment but also delivering the relevant, time-sensitive message.

${ }^{40}$ Por. E. TESAURO, Idea wymowy opartej na argucji i petnej finezji, w przekładzie i opra-
} 
Izokrates szczyci się, że rozwija swoją inwencję twórczą w tym kierunku, by wzbogacać tworzone przez siebie mowy o „enthymematy” coraz nowsze i bogatsze treścią ${ }^{41}$, i tego też - w myśl postulatu: „dobrze mówić i rozumnie myśleć" 42 - wymaga od swoich uczniów. Przygotowanie retoryczne, jakie oferuje podopiecznym w swoim zakładzie wychowawczym, nie polega bynajmniej na tym, że stosują się oni jedynie do przyjętych wzorów, lecz stawiani są wobec zadań, które wyzwalają ich inwencję i aktywność myślową. Stają się kreatywnymi uczestnikami procesu dydaktycznego ${ }^{43}$ i tym samym żywym zaprzeczeniem krytykowanej przez Izokratesa „topornej” dydaktyki sofistycznej.

Warto dodać, że z tym ważnym dla Izokratesa postulatem ciągłej aktywności myślowej idzie w parze wymóg myślenia krytycznego, w tym również krytycyzmu, jaki należy wykazać w stosunku do samego siebie. Swą wierność tej zasadzie dokumentuje on niejednokrotnie własnym przykładem, chociażby wtedy, gdy dokonuje swoistego „przewartościowania” treści swej wypowiedzi w aspekcie czynionych wcześniej założeń (Paneg. 187), czy wtedy, gdy z jakimś nawet wewnętrznym ,wzburzeniem” ( $\tau \alpha \rho \alpha \chi \eta)$ poddaje ocenie to, co napisał (Panath. 233), czy to, czego w życiu dokonał (Panath. 7). Sędziwy nauczyciel etycznie uzdrowionej retoryki staje się tym samym dla otaczających go młodych ludzi uosobieniem jeszcze jednej cennej etycznej zalety.

\section{STYLISTYCZNA I EUFONICZNA JAKOŚĆ PRZEKAZU}

Ostatni już z warunków, jakie stawia Izokrates przed dobrze przygotowanym retorem, pozostaje u niego w niewątpliwym związku z powyższym postulatem inwencji myślowej, skoro już w mowie „Przeciw sofistom” wymaga od takiego mówcy, by nie tylko „przyozdabiał” mowę ,enthymematami”, lecz

cowaniu Iwony Słomak i Kacpra Kardasa, TERMINUS 17(2015), z. 2, s. 37-416; s. 397: Toteż termin enthymema trafnie stosuje się na oznaczenie argumentu bystro pomyślanego albo też stwierdzenia celnego i przekonującego.

${ }^{41}$ Isocr. Antid. 47, por. Panath. 2.

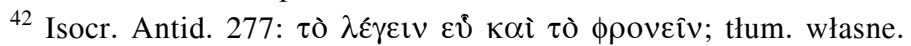

${ }^{43}$ Por. A. MAthiesen, Edukacja retoryczna jako element ksztattowania madrości politycz$n e j$, ,Ethics in Progress” 7(2016), 2, s. 58-81; s. 71: To powiązanie natury (predyspozycji) i sztuki (rozumianej jako praktyka i doświadczenie) dawało nadzieje na uzyskanie pozytywnych efektów wychowawczych wśród uczniów, którzy nie tyle [!] podlegali retorycznej pajdei, ale także sami ją kultywowali, jednocześnie pracując nad własnym doskonaleniem się w cnocie obywatelskiej. 
również dobierał „takie słowa, aby była melodyjna i rytmiczna" 44 , a jeszcze w schyłkowym swoim „Panatenaiku”, charakteryzując własny sposób wypowiadania się, owe „entymematy” wymienia łącznie z nazwami niektórych figur retorycznych (Panath. 2). Błędem byłoby oczywiście przypisywać wymogowi pięknego brzmienia wypowiedzi nadmierne znaczenie w Izokratejskiej koncepcji etycznie poprawnej retoryki, skoro podstawowy walor przekazu retorycznego stanowić ma jego argumentatywność opartą o zdrowe zasady moralne, niemniej jest to jeszcze jeden warunek decydujący o profesjonalizmie mówcy, warunek, który nota bene wychodzi naprzeciw preferencjom odbiorcy. Już w mowie „O pokoju” ubolewa Izokrates nad faktem, że ówcześni słuchacze zdemoralizowali retorów, którzy w rezultacie zamiast dążyć do tego, co niesie państwu pożytek, starają się przemawiać w sposób, który będzie się tamtym podobać (De pace 5).

Warunku eufonii przekazu retorycznego nie należy z pewnością trywializować, jako że owa eufonia nie oznacza jedynie ozdobności stylu, lecz ściśle wiąże się u Izokratesa z kompozycyjną doskonałością tekstu, uporządkowanego i przejrzystego tak w warstwie argumentatywnej, jak i na poziomie opracowania językowego ${ }^{45}$. Postulatu, o którym mowa, nie należy też bagatelizować, skoro - zgodnie z powyższą konstatacją samego Izokratesa - niebywale zwiększa on szanse mówcy na to, by mógł dopiąć swych słusznych celów, by mógł, „wywołując przyjemność na poziomie stylistycznego dopracowania mowy, odważnie stawać w obronie tego, co najlepsze"46. Jeżeli natomiast chodzi o sam walor eufoniczny przekazu retorycznego, stanowisko Izokratesa nie jest z pewnością skrajne i nie jest z drugiej strony niewzruszo-

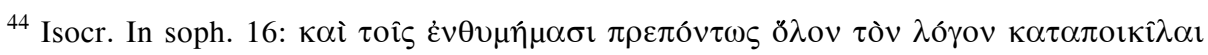

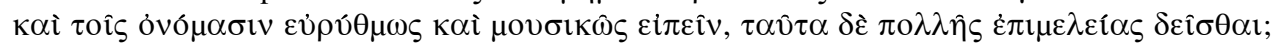
tłum. M. Dobrek (,Meander” 62(2007), 3-4, s. 237).

${ }^{45}$ Por. J. JANIK, Izokrates - pisarz, s. 70: W słowach kończących mowę autor wraca do kluczowej w jego mniemaniu kwestii dopracowania wystąpienia, staranności stylu i przemyślanej argumentacji. Trudno wątpić, że właśnie z owej staranności Izokrates był dumny, a styl drobiazgowo wypracowanych mów przeciwstawiał wystąpieniom mniej starannym; por. M. WESOŁY, Skad się wzięta retoryka? Perspektywa Arystotelesa, w: Retoryka klasyczna i retoryka wspótczesna. Pola i perspektywy badań, red. C. Mielczarski, Warszawa: Wydawnictwo Naukowe Sub Lupa 2017, s. 13-49; s. 45: Izokrates, jak wiadomo, ogromne znacznie przypisywał do układu i stylu swych mów, które latami wypracowywał.

46 Por. K. Morgan, The Education of Athens: Politics and Rhetoric in Isocrates, w: Isocrates and Civic Education, s. 125-154; s. 134: The Isocratean politician, then, must charm and please the audience while giving good advice. His speeches cause pleasure on the stylistic level while fearlessly advocating what is best.
} 
ne, o czym dowiadujemy się z jego własnych na ten temat deklaracji, ale też dzięki świadectwu Marka Tulliusza Cycerona.

Cycero, który charakterystycznym dla Izokratesa rozwiązaniom składniowo-stylistycznym poświęca szereg wzmianek w swoim traktacie „Mówca”, jest w ogóle zdania, że pisał ów autor nie tylko po to, by zwyciężać w argumentatywnym agonie, lecz niekiedy głównie po to, by wywoływać przyjemność organu słuchowego odbiorcy ${ }^{47}$. Jeżeli natomiast chodzi o konkretne rozwiązania służące wywołaniu takiego efektu, Cycero wskazuje przede wszystkim na to, że Izokrates wprowadził w wypowiedź z gatunku prozy właściwe poezji miary metryczne (175), a także zasadę unikania tzw. hiatu, czyli stykania się samogłosek na zbiegu sąsiadujących wyrazów (150-151), wspomina też szereg Izokratejskich figur stylistycznych wzmacniających efekt retoryczny, jak proporcjonalna współobecność wzajemnie odpowiadających sobie członów zdaniowych, lecz także łączenie określeń przeciwstawnych $(38,175)$, wreszcie zgodność brzmieniowa wyrazów zamykających bliskie sobie klauzule zdaniowe (38). Szczególną zasługę Izokratesa, jeżeli chodzi o formę retorycznej wypowiedzi, stanowić ma jednak to właśnie, że wprowadził okragłą, „zamkniętą" zdaniową klauzulę, opartą o doskonale wykończone sformułowania (207). Samą ozdobność Izokratejskiego stylu ocenia jednak Cycero jako umiarkowaną, doceniając powściągliwość tego retora w zakresie wzbogacania leksyki i stosowania przejętych od poetów miar wierszowych ${ }^{48}$.

Można przyjąć, że w ostatnio przytoczonej opinii Cycero „uśrednia” w jakiś sposób dane na temat stylu wypowiedzi retorycznej preferowanego przez Izokratesa, jakie przynosza jego pisma. Ów retor nie kładzie bowiem nacisku na umiar swej retorycznej stylistyki, lecz zdaje się wyróżniać dwie fazy w swoim nastawieniu do kwestii ozdobności stylu, z dość wyraźnym, acz późnym, w tym względzie przełomem. Zarówno bowiem w „Panatenaiku”, zamykającym jego dorobek, jak i w niewiele wcześniejszej mowie dedykowanej Filipowi zdradza, że w latach jego twórczej świetności mowy jego pełne były tez przeciwstawnych i wspomnianych proporcjonalnie odpowiadających sobie członów zdaniowych (Panath. 2), były też obficie zdobione frazami rytmicznymi i urozmaiceniami stylu, teraz jednak, gdy jest już stary, decyduje się na to, by wyrażać swoje myśli w sposób prosty $(\dot{\alpha} \pi \lambda \omega \varsigma)^{49}$. Można przy-

\footnotetext{
${ }^{47}$ Cic. Orator. 38: non enim ad iudiciorum certamen, sed ad voluptatem aurium scripserat.

${ }^{48}$ Cic. Orator 176: Horum uterque [Gorgiasz i Trazymach] Isocratem aetate praecurrit, ut eos ille moderatione, non inventione vicerit. Est enim, ut in transferendis faciendisque verbis tranquillior sic in ipsis numeris sedatior.

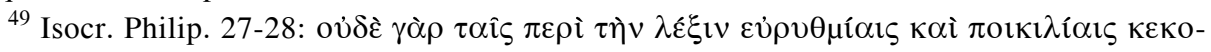


puszczać, że miejscem, w którym zbiegają się te dwie odmienne koncepcje stylistycznej jakości mowy, będzie pismo „O zamianie majątku”, również z tego względu reprezentatywne dla całej Izokratejskiej „filozofii” wymowy. Tu bowiem znajdziemy zarówno deklarację potwierdzającą staranie autora o pewną jednak ozdobność stylu (46-47), jak też wyrazy uznania dla attyckiej poprawności i umiaru w publicznym wypowiadaniu się (296), tu wreszcie jeszcze raz sformułowana zostaje generalna zasada, by mówić tak, aby przekonywać słuchaczy nie tylko tym, co się mówi, lecz także harmonijnym brzmieniem wypowiedzi ${ }^{50}$.

Przedstawienie całego „pakietu” wymogów, których spełnienie decyduje dla Izokratesa o profesjonalizmie i etycznie słusznej postawie retora, wyczerpuje w zasadzie temat niniejszych rozważań, pozostaje jednak pewna kwestia, którą wypada podjąć już z uwagi na to, że niejednokrotnie dawała o sobie znać powyżej. Kwestia ta wyraża się pytaniem, w jakim stopniu twórca owej koncepcji własną praktyką retoryczną egzemplifikował te piękne zasady etyczne, a w jakim pozostały one wyłącznie teorią, czy nawet pozorem, zręcznie wspomagającym starania Izokratesa o to, by jako moralny autorytet wybić się ponad mało chwalebny standard ówczesnej retoryki. Pytanie dotyczy zatem motywacji autora omówionej koncepcji retorycznej, które - jak utrzymuje T. Behme - miały charakter bardzo osobisty i ambicjonalny. Otóż Izokrates ze swoją „obsesją", by był absolutnie oryginalny, kierować się miał przede wszystkim pragnieniem zdobycia sławy, majątku oraz nieśmiertelności ${ }^{51}$. Trudno nie zauważyć, iż przypisane mu tak małostkowe ambicje ciążą nie tylko na jego własnym wizerunku, lecz także w jakiejś mierze na ocenie przedstawionej powyżej koncepcji zdrowej etycznie retoryki. Autor niniejszych słów czuje się zatem w obowiązku, by odnieść się do zaprezentowanej opinii, tym bardziej że uznaje ją za krzywdzącą w stosunku do nauczyciela

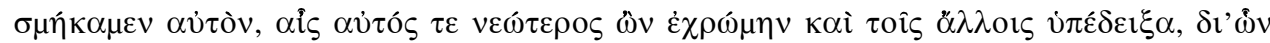

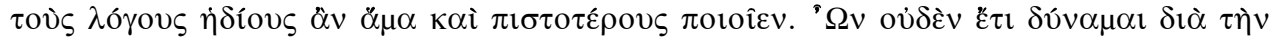

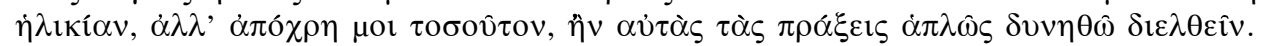

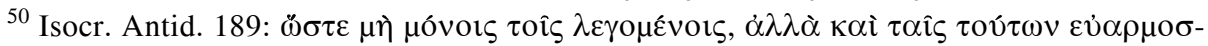

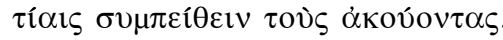

${ }^{51}$ Por. T. BEHME, Isocrates on the Ethics of Authorship, „Rhetoric Review” 23(2004), 3, s. 197-215; s. 197: Isocrates was obsessed with originality; his motivations for writing included the pursuit of fame, fortune, and immortality; por. s. 205: His writings clearly indicate that he was competing for fame, fortune, and immortality. 
i wzoru dla kolejnych pokoleń retorów, którym niewątpliwie był Izokrates. O tym, że autor mowy „O zamianie majątku” nie kieruje się żądzą doraźnego zysku i w ogóle ambicją zyskiwania bogactw, świadczy już jego (wskazana powyżej) powściągliwość w składaniu obietnic „pajdeutycznych”, a jeszcze wymowniej okoliczność, iż nie ubiega się o jakiekolwiek świadczenia ze strony państwa, nie chcąc pozbawiać tego wsparcia bardziej potrzebujących obywateli (Antid. 152), oraz powstrzymuje się od pełnienia przynoszących niezłe zyski publicznych urzędów, czy równie zyskownej praktyki w sądach (Antid. 150). Izokrates w ogóle żyje w ukryciu i - jak wiadomo - nie decyduje się na publiczne wystąpienia, co tłumaczy słabym głosem i brakiem odwagi, ów brak odwagi może jednak oznaczać nie tyle lęk samozachowawczy, ile pewną powściągliwość natury etycznej. Nie ma on, co w jakiś sposób zdradza jego mowa „Do Filipa”, na tyle czelności, by manipulować tłumem, rywalizując przy tym we wzajemnych obelgach i złorzeczeniach z demagogami, którzy na co dzień okupują mównicę ${ }^{52}$.

Nie jest Izokrates z pewnością osobą „przebojową” i nie wydaje się też nadmiernie przywiązany do swojej osoby. Wiele wskazuje na to, że swoje uczucia i aspiracje przenosi w coraz większym stopniu na wychowanków, co można uznać za jakąś realizacją przypisanego mu pragnienia nieśmiertelności, a jego niezaprzeczalne ambicje przywódcze wiążą się przede wszystkim z poczuciem misji, jaką podejmuje i chce doprowadzić do końca, główną jednak w tym względzie jego motywacją wydaje się świadomość powinności, którą ma względem swego miasta i pozostałych Greków. W jego przekonaniach i sposobie bycia z kolei zwraca uwagę skromność łączona z krytycyzmem wobec siebie samego oraz szacunkiem dla innych ludzi, niewątpliwa kultura osobista, a także ceniona przez Greków stabilność zachowań i poglądów. Tę piękną postawę „stałości” ( $\beta \varepsilon \beta \alpha \iota \delta \tau \eta \varsigma)$ deklaruje on osobiście (Antid. 195), lecz wymowniej jeszcze poświadcza ją fakt, iż na przestrzeni około czterdziestu lat, jakie dziela jego mowy „Przeciw sofistom” oraz „O zamianie majątku”, głosi niezmiennie te same poglądy etyczno-pedagogiczne.

Garść przedstawionych powyżej spostrzeżeń, które mogą prowadzić do konkluzji, że dla Izokratesa „moralne postępowanie pozostawało czymś więcej niż retoryczną strategią" ${ }^{33}$, nie przesądza oczywiście kwestii, jak bardzo

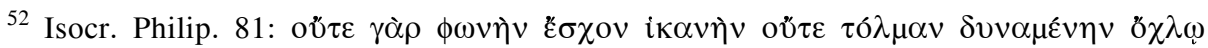

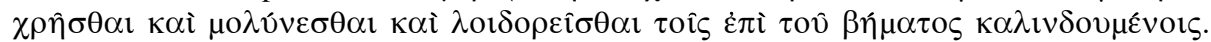

${ }^{53}$ Por. Ch. MARsh, Millenia, s. 292: Isocrates' pride in his graduates who, by his standards, led moral lives outside the public sphere clearly shows, however, that, for him, moral action remained more than a rhetorical strategy.
} 
wierny był on zasadom, jakie głosił, niemniej w znacznym stopniu dyskredytuje opinię przypisującą mu ambicje niegodne etycznego wzoru. Nie stanowiła jednak przedmiotu powyższych rozważań ocena etycznej postawy samego Izokratesa, która zresztą - co istotniejsze - nie musi wiązać się z oceną przedstawionego programu uzdrowionej etycznie retoryki. Żaden bowiem teoretyk, ani nawet propagator określonych zasad teoretycznych, nie jest zobowiązany do tego, by własnym postępowaniem wcielał w życie program, jaki głosi, podobnie jak autor podręczników medycznych, czy nawet praktykujący lekarz, by dobrze sprawował swoją funkcję, nie musi być okazem zdrowia, czy nawet osobiście stosować się do zaleceń zdrowotnych, jakich udziela innym. Nie rozliczajmy zatem Izokratesa z jego osobistej wierności formułowanym przez niego pięknym zasadom etyki retorycznej, skoro jawi się on jako ktoś, kto już przestaje być tuzinkowym „moralistą”, a wznosi się na poziom, na którym staje się proklamatorem kompleksowego programu ,etyki perswazywnej”, jaki decyduje o kształcie ,jego własnego dyskursu", lecz i wytycza pewien konstruktywny ideał dla społeczności, w której żyje ${ }^{54}$.

\section{BIBLIOGRAFIA}

BEHME T.: Isocrates on the Ethics of Authorship, „Rhetoric Review” 23(2004), 3, s. 197-215.

CHASE K.R.: Constructing Ethics through Rhetoric: Isocrates and Piety, „Quarterly Journal of Speech" 95(2009), No. 3, s. 239-262.

EUCKEN Ch.: Isokrates. Seine Positionen in der Auseinandersetzung mit den zeitgenössischen Philosophen, Berlin 1983.

GARVER E.: Philosophy, Rhetoric, and Civic Education in Aristotle and Isocrates; w: Isocrates and Civic Education, red. T. Poulakos, D. Depew, Austin: University of Texas Press 2004, s. $186-213$.

HASKINS E.: Logos and Power in Sophistical and Isocratean Rhetoric, w: Isocrates and Civic Education, red. T. Poulakos, D. Depew, Austin: University of Texas Press 2004, s. 84-103.

JANIK J.: Izokrates - pisarz czy mówca? Kilka uwag o kompozycji „Panegiryku”. „Quaestiones Oralitatis" 2(2016), nr 1, s. 55-74.

MARSH Ch.W.: Public Relations Ethics: Contrasting Models from the Rhetorics of Plato, Aristotle, and Isocrates, „Journal of Mass Media Ethics” 16(2001), 2-3, s. 78-98.

MARSH Ch.: Millennia of discord: The controversial educational program of Isocrates, „Theory and Research in Education" 8(2010), 3.

\footnotetext{
${ }^{54}$ Por. K.R. CHASE, Constructing Ethics, s. 254: Isocrates was more than a moralizer; he enacted an ethic of persuasion that simultaneously constituted his own discourse and held forth formative ideals for his society.
} 
MATHIESEN A.: Edukacja retoryczna jako element kształtowania mądrości politycznej, „Ethics in Progress" 7(2016), 2, s. 58-81.

Morgan K.: The Education of Athens: Politics and Rhetoric in Isocrates, w: Isocrates and Civic Education, red. T. Poulakos, D. Depew, Austin: University of Texas Press 2004, s. $125-154$

Poulakos J.: Rhetoric and Civic Education: from the Sophists to Isocrates, w: Isocrates and Civic Education, red. T. Poulakos, D. Depew, Austin: University of Texas Press 2004, s. $69-83$.

Poulakos T.: Speaking for the Polis. Isocrates' Rhetorical Education, Columbia: University of South Carolina Press 1997.

RomiLly de J.: Eunoia in Isocrates or the Political Importance of Creating Good Will, „The Journal of Hellenic Studies" 78(1958), s. 92-101.

TESAURO E.: Idea wymowy opartej na argucji i pełnej finezji, w przekładzie i opracowaniu Iwony Słomak i Kacpra Kardasa, TERMINUS 17(2015), z. 2, s. 379-416.

WALTERS F.D.: Isocrates and the Epistemic Return: Individual and Community in Classical and Modern Rhetoric, „Journal of Advanced Composition” 13(1993), s. 155-172.

WAREH T.: The Theory and Practice of Life. Isocrates and the Philosophers, Cambridge: Harvard University Press 2012.

WeSOŁY M.: Skąd się wzięła retoryka? Perspektywa Arystotelesa, w: Retoryka klasyczna i retoryka współczesna. Pola i perspektywy badań, red. C. Mielczarski, Warszawa: Wydawnictwo Naukowe Sup Lupa 2017, s. 13-49.

Yun LEE ToO: The Rhetoric of Identity in Isocrates, Cambridge: Cambridge University Press 2009 (first publ. 1995).

\section{IZOKRATES NA TEMAT ETYCZNEJ WARTOŚCI PRZEKAZU RETORYCZNEGO}

\footnotetext{
St r e s z c z e n i e
}

Przedmiotem artykułu jest teoria etycznej retoryki Izokratesa, słusznie uważanego za prekursora idei etyki komunikacji lingwistycznej. Autor artykułu koncentruje się na następujących aspektach zagadnienia: kwestii prawdy i odpowiedzialności za słowo, etycznym postępowaniu retora, jego zaangażowaniu politycznym, sympatii do innych ludzi, własnej nieustającej aktywności umysłowej i wreszcie jego trosce o stylistyczną i eufoniczną jakość przekazu. Ostatnie uwagi dotyczą problemu, czy Izokrates rzeczywiście przestrzegał zasad retorycznych, które głosił.

Słowa kluczowe: Izokrates; retoryka; etyka; zbiór zasad. 
ISOCRATES ON THE ETHICAL VALUE OF RHETORICAL MESSAGE

\section{S u m m a r y}

The subject of the article is the theory of ethically-based rhetorics of Isocrates, rightly regarded as the precursor of the idea of lingustic communication ethics. The author of the article focuses on the following aspects of the issue: the question of truth and taking responsibility for one's words, the ethical conduct of rhetorician, his political involvement, his sympathy towards other people, his self-imposed regular mental activity and finally his care for stylistic and eufonic quality of his message. The final remarks concern the problem whether Isocrates actually followed the rhetoric principles he proclaimed.

Key words: Isocrates; rhetoric; ethics; set of principles. 